\title{
Loss and damage from climate change: local-level evidence from nine vulnerable countries
}

\author{
Koko Warner* and Kees van der Geest \\ Institute for Environment and Human Security (UNU-EHS), \\ UN Campus, \\ United Nations University, \\ Platz der Vereinten Nationen 1, \\ D-53113 Bonn, Germany \\ E-mail: warner@ehs.unu.edu \\ E-mail: kgeest@gmail.com \\ *Corresponding author
}

\begin{abstract}
Loss and damage is already a significant consequence of inadequate ability to adapt to changes in climate patterns. This paper reports on the first ever multi-country, evidence-based study on loss and damage from the perspective of affected people in least developed and other vulnerable countries. Researchers in Bangladesh, Bhutan, Burkina Faso, Ethiopia, the Gambia, Kenya, Micronesia, Mozambique and Nepal conducted household surveys $(n=3,269)$ and more than a hundred focus group discussions and open interviews about loss and damage. The research reveals four loss and damage pathways. Residual impacts of climate stressors occur when: 1) existing coping/adaptation to biophysical impact is not enough; 2) measures have costs (including non-economic) that cannot be regained; 3) despite short-term merits, measures have negative effects in the longer term; or 4) no measures are adopted - or possible - at all
\end{abstract}

Keywords: loss and damage; climate change; adaptation; adaptation limits; coping strategies; vulnerability; food security; livelihood security.

Reference to this paper should be made as follows: Warner, $\mathrm{K}$. and van der Geest, K. (2013) 'Loss and damage from climate change: local-level evidence from nine vulnerable countries', Int. J. Global Warming, Vol. 5, No. 4, pp.367-386.

Biographical notes: Koko Warner is a Section Head (Environmental Migration, Social Vulnerability, and Adaptation) and Executive Director (Munich Climate Insurance Initiative) at the United Nations University, Institute for Environment and Human Security (UNU-EHS). Her research interests include limits of adaptation and consequences for loss and damage, human mobility, and risk management.

Kees van der Geest is a Senior Researcher at the United Nations University, Institute for Environment and Human Security (UNU-EHS) in the Environmental Migration, Social Vulnerability, and Adaptation Section. His research interests include impacts of climate change, vulnerability, adaptation, livelihoods, environment, development and human mobility. 
This paper is a revised and expanded version of a paper entitled 'Evidence from the frontlines of climate change: Loss and damage to communities despite coping and adaptation' presented at United Nations University Scientific Conference: 'Perspectives on Loss and Damage: Society, Climate Change, and Decision Making', Bonn, Germany, 25-28 February, 2013.

\section{Introduction}

Science points to widespread current and future biophysical impacts of anthropogenic climate change (IPCC, 2007a, 2007b, 2012; Fung et al., 2011; Thornton et al., 2011). Current trajectories of greenhouse gas emissions call into question whether targets to keep global temperatures within $2^{\circ} \mathrm{C}$ can be met (Meinshausen et al., 2009; van Vliet et al., 2012). This in turn raises issues about a 'safe operating space' (Röckstrom et al., 2009) for humanity, and the consequences for human society of crossing interacting biophysical boundaries of Earth systems and social dimensions of limits to adaptation (Adger et al., 2009a; Preston et al., 2013; O’Brien, 2010; O’Brien and Wolf, 2010).

Negotiating these boundaries is, in part, a task of adaptation, the success of which may lie in the ability to keep systems from exceeding these boundaries (Moser, 2009; Patt and Schröter, 2008; Adger et al., 2009b). Preston et al. (2013) introduce the concept of an 'adaptation frontier', which they define as "a socio-ecological system's transitional adaptive operating space between safe and unsafe domains" and relate it to vulnerability and resilience, which determine how well a system can continue to exist within a 'safe operating space' before reaching a limit [Preston et al., (2013), p.1014].

While systems will continually change and adjust to stressors (Adger et al., 2003), 'adaptation deficits' (Burton, 2009), barriers, and limits to adaptation exist and can impede sustainable development (Preston et al., 2013; Kates et al., 2012; Schipper, 2007; McGray et al., 2007). A key question - and the focus of this paper - is what happens to key development goals when efforts to adjust are insufficient or not possible? What patterns of loss and damage emerge in human systems around these barriers and constraints to adaptation?

Some of the following gaps have been identified in the literature (see Berrang-Ford et al., 2011): which climate stressors are of greatest concern to human systems; how do climate stressors affect (sustainable) development objectives like food and livelihood security, poverty and health; what adaptive actions are undertaken proactively or reactively to manage these climate stressors; and what are the consequences of inadequate adaptation for actors. Evidence is needed about how society functions in the context of barriers and limits to adaptation, and what the consequences of exceeding limits at different scales might be, including residual loss and damage (the focus of this paper).

This article provides an overview of the nine case studies presented in this special issue of the International Journal of Global Warming. The case studies focus on loss and damage, and help address these gaps at household and community levels in developing countries. The results illustrate the circumstances under which households manage climatic stressors and resulting societal impacts, and the consequences of not being able to adjust sufficiently to negative impacts. 


\subsection{Understanding loss and damage around constraints and limits to adaptation}

For the community-based field research introduced in this article the following working definition of loss and damage was used:

Loss and damage refers to negative effects of climate variability and climate

change that people have not been able to cope with or adapt to.

This includes the inability to respond adequately to climate stressors and the costs and adverse effects associated with the adaptation and coping measures themselves. Such costs and adverse effects can be both economic and non-economic. Loss and damage is also related to mitigation, as the potential costs of future climate change depend to a large extent on the intensity of climatic disruptions, which in turn depend on mitigation efforts globally.

The empirical research on loss and damage aimed to enhance understanding of how the interaction of climatic variability and climate change with livelihoods and social vulnerability creates particular patterns of loss and damage today in least developed and developing countries.

To understand patterns of loss and damage in nuanced social-ecological contexts across the world, the case studies gathered data in four research domains:

1 Climate stressor: Manifestations of climate variability and climate change in specific ecosystems (for example, rainfall variability, droughts, floods, cyclones and tropical storms, glacial melt, sea-level rise, etc.). This could involve extreme weather-related events and more gradual changes.

2 Societal impact: Societal impacts related to climatic drivers of importance in a particular ecosystem (for example, impact on food production, livelihood security, health, damage to physical assets, etc.). Some impacts - like coastal erosion and salinity intrusion - result from both social and physical/climatic factors and their interactions.

3 Responses: What is done to adapt to changes in the frequency and severity of extreme weather-related events and slow-onset climate changes? And what is done to cope with societal impacts? The terms 'coping' and 'adaptation' are often used synonymously. This is problematic because they involve different types of responses to different types of stressors (van der Geest, 2004; Birkmann, 2011). In the loss and damage case studies, coping strategies were defined as short-term responses to the impacts of sudden events. Adaptation was defined as longer-term responses to more gradual changes (Warner et al., 2012b). We acknowledge that adaptation measures are adopted "in response to actual and expected impacts of climate change in the context of interacting nonclimatic changes" [Moser and Ekstrom, (2010), p.22026] and that such measures "aim to meet more than climate change goals alone" (ibid).

4 (Residual) loss and damage: What are the effects of climate variability and climate change that people have not (yet) been able to avoid? What are the limits and costs of adaptation to climatic changes? What happens to a household when its coping strategies are not effective enough to avoid or manage the impacts of extreme events? Loss and damage can result from an inability to respond to climate stressors, 
insufficient coping and adaptation measures, the costs associated with coping and adaptation strategies, and adverse long-term effects of adopted measures. These costs and consequences often elude quantification but cause severe harm and impede sustainable development.

\section{Methods of community-based assessment of loss and damage}

To generate evidence that helps fill gaps in the literature, field research was undertaken in nine vulnerable countries to determine how loss and damage is incurred by households, based on the interaction between climatic variability and factors such as livelihoods, health, and social/physical assets. The research approach explained in this section was developed as a prototype for community-based assessment of loss and damage.

\subsection{Research objective}

Each of the nine case studies addressed the same type of research questions, while focusing on different climatic stressors and societal impacts. Societal impacts could involve negative effects on livelihood sources, physical assets and other aspects of human well-being, such as housing and health. The central research question was as follows:

How does the impact of [climate variable] on [societal impact] lead to loss and damage among households in [location]?

The central research question was addressed through several sub-questions, focusing on

1 local changes in weather variability and climate patterns

2 societal impacts of these climate stressors

3 household vulnerability

4 existing coping and adaptation measures

5 residual losses and damage, defined as impacts that could not be avoided through coping and adaptation.

The research presented here generated primary data providing a people's perspective on loss and damage. Research was conducted in districts in nine countries especially vulnerable to loss and damage due to climate variability and climate change (Bangladesh, Bhutan, Burkina Faso, Ethiopia, the Gambia, Kenya, Micronesia, Mozambique and Nepal). National research teams in these countries gathered quantitative and qualitative data through household surveys $(n=3,269)$ and more than a hundred focus group discussions and interviews with key informants about their personal experiences of climate change impacts and about their responses. Researchers further compared local meteorological and other relevant data with local perceptions of changes in climatic stressors.

Table 1 provides an overview of the climate stressors and societal impacts on which each of the nine case studies focused. 
Table 1 Overview of the case studies: research area, climate stressors, societal impact and sample size

\begin{tabular}{lcccc}
\hline Country & District/region & $\begin{array}{c}\text { Climate-related } \\
\text { stressor }\end{array}$ & Societal impact focus $*$ & $\begin{array}{c}\text { Sample } \\
\text { size }\end{array}$ \\
\hline Bangladesh & Sathkira & Salinity intrusion & Rice + drinking water & 360 \\
Bhutan & Punakha & Changing monsoon & Rice production & 273 \\
Burkina Faso & Sahel & Drought & Livestock + crops & 465 \\
Ethiopia & Gambella & Flooding & Habitability + livelihood & 431 \\
Gambia & North Bank & Drought & Millet production & 373 \\
Kenya & Budalangi & Flooding & Crops, livestock + fish & 400 \\
Micronesia & Kosrae & Coastal erosion & Housing, livelihood & 363 \\
Mozambique & South and central & Drought and flood & Staple crops & 304 \\
Nepal & Udayapur & Flooding & Agricultural livelihood & 300 \\
\hline
\end{tabular}

Note: *Each case study focused on one or more particular impact sectors, but also registered impacts in other sectors.

\subsection{Site selection}

The sites were selected to cover a wide range of ecosystems, geographic regions (drylands, mountains, a small island, a delta) and climatic stressors (droughts, floods, cyclones, sea-level rise, glacial melt, desertification, changing rainfall patterns) as well as dependence of livelihoods on climate conditions (e.g., rainfed agriculture, fishing, herding). Other important considerations included exploring cross-cutting issues related to climate stressors, such as food production, human and livelihood security, social justice and cohesion, and human mobility.

\subsection{Mixed methods research approach}

The methods developed for this project build on prior empirical research methods at UN University, such as the 'Where the Rain Falls' project (Warner et al., 2012a; Rademacher-Schulz et al., 2012), supplemented with insights from fieldwork-based studies of livelihood vulnerability, coping and adapting, particularly in rural agricultural environments emerging from the late 1990s onwards (Davies, 1996; Ellis, 1998; Scoones, 1998; Bebbington, 1999). This methodology is described below and the research instruments are available at $\mathrm{http}: / / \mathrm{www}$.ehs.unu.edu and http://www.lossanddamage.net.

In preparation for each case study, a desk-study was conducted to collect and analyse existing regional and thematic literature and secondary data serving as an input to final decisions about research design and on the selection of climate stressors and impact sectors on which to focus. The survey instrument (sample size: 273 to 465 households per case study, with a total of 3,269 households) aimed to generate reliable estimations of the numbers of people in the research areas experiencing different climate change impacts and their strategies to deal with climate pressures and shocks. A template questionnaire was designed and later adapted for each case study to suit its thematic focus and the characteristics of local livelihood systems and environments. The first section of the survey instrument enquired about household socio-economic and demographic 
characteristics and about sources of food and income. The information gathered in this section can be used to create vulnerability profiles, comparing households in one location or across case study areas. Sections 2 and 3 dealt with extreme weather events and slowonset processes with a focus on impact, coping, adaptation and residual loss and damage. Open questions were combined with closed question to optimise the balance between listening to the voices of vulnerable people and being able to quantify how widespread different impacts and responses are.

In each case study area, open interviews were conducted with five to ten questionnaire respondents to hear their personal stories of impacts, responses and residual loss and damage. These stories complement the somewhat de-personalised analyses of the survey instrument. Focus group discussions were organised to gather more qualitative information on the complex dynamics between the key concepts of this research climate variability and changes, societal impacts, vulnerability, coping, adapting, and residual impacts. The focus group discussions also allowed researchers to detect differences in the experiences of men and women, young and old, and different occupational groups (e.g., crop cultivators, pastoralists, labourers, traders) and wealth groups.

\subsection{Limitations}

The limitations of the research objective and methods include:

1 attribution of local climatic changes and extreme events to global warming is beyond the scope of this research

2 no attempt was made to estimate total monetary loss and damage at local, national or global scales

3 the local case studies are not necessarily representative of entire countries.

Findings do not support or negate any particular political position on loss and damage. Rather, they offer evidence that support policymakers in discussions about underlying needs that inform solutions. The study and its methods should be treated as points of departure for further research on loss and damage in vulnerable communities.

\section{Summary of findings presented in special issue}

This section gives an overview of findings from the nine case studies. More in-depth analyses of the situation in individual case study areas are published in separate papers in this special issue, and Section 4 discusses four 'loss and damage pathways', illustrated with examples from the field. Table 2 shows the percentage of households in each research site experiencing particular climate-related stressors and impacts on their household economy, the proportion of households that adopted coping or adapting measures, and the proportion of households incurring residual loss and damage. The large majority of survey respondents across study sites indicated they adopted coping or adaptation measures to counter adverse effects of extreme weather events and slow-onset changes (median: $88 \%$, see Table 2). 
Table 2 Stressors, impact, responses and loss and damage ( $\%$ of households)

\begin{tabular}{|c|c|c|c|c|c|c|}
\hline & & (a) & (b) & (c) & (d) & (e) \\
\hline Country & $\begin{array}{l}\text { Climate- } \\
\text { related stressor }\end{array}$ & $\begin{array}{c}\text { Experienced } \\
\text { stressor } \\
(\%)\end{array}$ & $\begin{array}{c}\text { Experienced } \\
\text { impact } \\
(\%)\end{array}$ & $\begin{array}{l}\text { Adopted } \\
\text { measures } \\
(\%)\end{array}$ & $\begin{array}{l}\text { Impact } \\
\text { despite } \\
\text { measures } \\
(\%)\end{array}$ & $\begin{array}{c}\text { Loss and } \\
\text { damage } \\
(\%)\end{array}$ \\
\hline Bangladesh & $\begin{array}{l}\text { Salinity } \\
\text { intrusion }\end{array}$ & 99 & 99 & 81 & 70 & 74 \\
\hline Bhutan & $\begin{array}{l}\text { Changing } \\
\text { monsoon }\end{array}$ & 91 & 89 & 88 & 87 & 72 \\
\hline Burkina Faso & Drought & 98 & 99 & 79 & 72 & 76 \\
\hline Ethiopia & Flood & 100 & 100 & 98 & 96 & 96 \\
\hline Gambia & Drought & 100 & 97 & 93 & 66 & 66 \\
\hline Kenya & Flood & 100 & 98 & 93 & 72 & 72 \\
\hline Micronesia & Coastal erosion & 87 & 80 & 60 & 92 & 66 \\
\hline Mozambique & Drought/flood & 100 & 99 & 93 & 69 & 70 \\
\hline Nepal & Flood & 97 & 74 & 72 & 78 & 60 \\
\hline Median & & 99 & 98 & 88 & 72 & 72 \\
\hline
\end{tabular}

Note: Column (b) is a proportion of the households in column (a); column (c) is a proportion of those in column (b); and column (d) is a proportion of those in column $(c)$. 'Loss and damage' in column $(e)$ is calculated as: $e=(a * b * c * d)+$ $((1-c) * a * b)$, where the letters stand for the percentages in the corresponding columns. In words, it is the proportion of the whole survey population that experienced adverse effects despite adopting measures to cope or adapt plus those who were affected but who did not adopt any measures in response.

Table 3 provides more detail about the impacts per sector. Table 4 details the coping strategies adopted to deal with impacts of floods and droughts in six of the case studies. For the other three research sites, with more diverse and slower-onset climatic stressors, the most common adaptation measures are listed in Table 5. Households in these areas had to deal with reduced availability of water for rice cultivation (Bhutan), coastal erosion (Micronesia) and salinity intrusion (Bangladesh), related to changing monsoon patterns, sea-level rise, cyclones and tropical storms.

Climate-related stressors are widely experienced in the research sites. For example, in Punakha District in Bhutan, 91\% of the households surveyed experienced changes in monsoon patterns that affected water availability for irrigated rice farming. In Satkhira District in Bangladesh, 99\% experienced saltwater intrusion. In the African case studies, 98 to $100 \%$ had experienced droughts or floods (see Table 2). The proportion of respondents for whom the climate stressor had a negative impact on household economy was also high, especially in Bangladesh and the African study sites ( $>97 \%)$. Impacts on crop cultivation and food prices were most common (see Table 3). As the large majority of respondents practise subsistence agriculture, with often limited access to non-farm income, crop failures often result in food insecurity. This is aggravated when food prices rise in the aftermath of, for example, a drought. In drought-affected areas, many households also reported severe impacts on livestock; and in study sites with frequent flooding, damage to physical assets, particularly houses, was common. 
Table 3 Impact sectors (\% of households)

\begin{tabular}{lcccc}
\hline Country & $\begin{array}{c}\text { Climate-related } \\
\text { stressor }\end{array}$ & $\begin{array}{c}\text { Impact sector } 1 \\
(\%)\end{array}$ & $\begin{array}{c}\text { Impact sector 2 } \\
(\%)\end{array}$ & $\begin{array}{c}\text { Impact sector 3 } \\
(\%)\end{array}$ \\
\hline Bangladesh & Salinity intrusion & Crops (98) & Drinking water (90) & N/A \\
Bhutan & Changing monsoon & Crops (97) & Trees (23) & Livestock (12) \\
Burkina Faso & Drought & Crops (96) & Food prices (90) & Livestock (87) \\
Ethiopia & Flood & Crops (94) & Health (92) & House (79) \\
Gambia & Drought & Crops (99) & Food prices (89) & Livestock (74) \\
Kenya & Flood & Crops (98) & Food prices (95) & Phys. assets (66) \\
Micronesia & Coastal erosion & Trees (70 & Crops (69) & Phys. assets (53) \\
Mozambique & Drought/flood & Crops (100) & Food prices (83) & Livestock (35) \\
Nepal & Flood & Crops (86) & Food prices (61) & Phys. assets (33) \\
\hline
\end{tabular}

Note: Percentages calculated over the households that experienced the climate threat (see Table 2).

Table 4 Coping measures adopted in response to impacts of floods and droughts ( $\%$ of households)

\begin{tabular}{lccccccc}
\hline Coping strategy & $\begin{array}{c}\text { BUR/ } \\
\text { drought }\end{array}$ & $\begin{array}{c}\text { ETH/ } \\
\text { flood }\end{array}$ & $\begin{array}{c}\text { GAM/ } \\
\text { drought }\end{array}$ & $\begin{array}{c}\text { KEN/ } \\
\text { flood }\end{array}$ & $\begin{array}{c}\text { MOZ/ } \\
\text { both }\end{array}$ & $\begin{array}{c}\text { NEP/ } \\
\text { flood }\end{array}$ & Median \\
\hline Rely on aid & 51 & 76 & 48 & 76 & 45 & 58 & 54.5 \\
$\begin{array}{l}\text { Seek other income to buy } \\
\text { food }\end{array}$ & 33 & 58 & 69 & 36 & 67 & 43 & 50.5 \\
$\begin{array}{l}\text { Support from social network } \\
\text { Sell assets/livestock to buy }\end{array}$ & 29 & 50 & 47 & 35 & 31 & 49 & 41.0 \\
food & 79 & 42 & 55 & 19 & 34 & 31 & 34.0 \\
Migration/relocation & 41 & 18 & 25 & 59 & 12 & 24 & 24.5 \\
Modify food consumption* & 87 & 78 & 64 & 82 & 79 & 40 & 78.5 \\
\hline
\end{tabular}

Notes: *Modifying food consumption may not be considered a coping strategy, but rather a consequence of limited coping capacity

- Percentages calculated over households that reported impacts of climatic stressors (see Table 2).

- $\mathrm{BUR}=$ Burkina Faso, ETH $=$ Ethiopia, GAM $=$ The Gambia, KEN $=$ Kenya, $\mathrm{MOZ}=$ Mozambique, NEP $=$ Nepal.

The questionnaire used in the fieldwork contained open as well as closed questions about coping and adaptation strategies. In the case of coping strategies that households adopted to deal with impacts of droughts and floods (Table 4), the closed questions actually covered almost all the coping mechanisms people used. Reliance on aid was particularly important where people had to deal with flood impacts (Ethiopia, Kenya and Nepal). In the case studies that focused on droughts (Burkina Faso and Gambia), selling livestock to buy food when harvests fail was a common coping strategy. Many households across the research sites also tried to cope by engaging in non-farm income-generating activities when their usual, more climate-sensitive, source of food and money was affected by drought or flood. Social networks played an important role in people's coping behaviour. The people who supported with money to buy food and other essentials in the aftermath 
of a drought or flood were often migrant relatives. The least frequent, but still important, coping strategy involved movement of whole households or individual household members to areas that were safe (in the case of flooding) or that provided opportunities to earn an income to buy food when their own harvests failed.

The last row in Table 4 shows the proportion of households that modified food consumption to deal with the impacts of drought or flood. One could wonder whether reducing the number of meals per day or portion sizes is a 'coping' strategy or a sign that available options to cope are failing. The high proportion of households that indicated they had to modify food consumption (median: 78.5\%) is a first sign that the threats posed by climate-related stressors are beyond people's capacity to cope.

Table 5 lists the most common adaptation measures adopted in the study sites where interacting climate extremes like cyclones and tropical storms and slow-onset climatic stressors, such as sea-level rise and changing rainfall patterns, were more prominent. Contrary to the coping strategies used to deal with drought and flood impacts, adaptation measures were much more diverse across the study sites. The most common adaptation strategies involved preventive measures that aimed to avoid or minimise the impacts of climate stressors. For example, in Bangladesh many farming households affected by salinity intrusion adapted by reducing livelihood dependency on agriculture. Many also adapted by planting new rice cultivars that are more tolerant to salinity (Rabbani et al., 2013).

Table 5 Adaptation measures adopted in response to slow-onset climatic changes ( $\%$ of households)

\begin{tabular}{lll}
\hline Country & $\begin{array}{c}\text { Climate-related } \\
\text { stressor }\end{array}$ & \multicolumn{1}{c}{$\begin{array}{c}\text { Adaptation strategies adopted to reduce future impacts or to } \\
\text { deal with current impacts }\end{array}$} \\
\hline Bangladesh & $\begin{array}{l}\text { Salinity } \\
\text { intrusion }\end{array}$ & $\begin{array}{l}\text { Reduce dependence on crop cultivation (60\%), plant } \\
\text { salt-resistant rice cultivars (39\%), on-farm measures to reduce } \\
\text { salinity }(27 \%)\end{array}$ \\
Bhutan & $\begin{array}{l}\text { Changing } \\
\text { monsoon }\end{array}$ & $\begin{array}{l}\text { Water-sharing arrangements }(48 \%), \text { more intensive } \\
\text { maintenance of irrigation channels (37\%), shift from rice to } \\
\text { other crops (31\%) }\end{array}$ \\
Micronesia & Coastal erosion & $\begin{array}{l}\text { Build sea walls (29\%), land filling to protect coastline }(29 \%), \\
\text { plant trees along coastline (15\%), raise houses (11\%) }\end{array}$ \\
\hline
\end{tabular}

Note: Percentages calculated over households that reported impacts of climatic stressors (see Table 2).

Among the people who adopted coping and adaptation measures, most were not fully successful in avoiding residual impacts. For example, in the Bhutan study area, $87 \%$ of households that adopted measures to deal with changing monsoon patterns and reduced availability of water for rice cultivation reported that they were still experiencing adverse effects despite the adaptation measures (Kusters and Wangdi, 2013). Similar results were found, albeit with a variety of different coping and adaptation measures, for all the other case studies (see Table 2). The last column of Table 2 shows the proportion of the survey population that incurred loss and damage, which was calculated as the sum of those who still experience adverse effects despite adopting measures to cope or adapt plus those who were affected, but did not adopt any measures in response (reasons for non-adoption are mentioned in Table 6). In eight of the nine study sites, this proportion was between 60 
and $78 \%$ (median $72 \%$ ). In Ethiopia, up to $96 \%$ of the households had incurred loss and damage from flooding.

The nine case studies help build our understanding of how households in affected communities attempt to manage both climatic stressors and societal impacts associated with extreme events and incremental climatic processes. The case studies illustrate that often the measures adopted by households are only partly successful in avoiding adverse effects of climate stressors.

Figure 1 Household potential for loss and damage (see online version for colours)

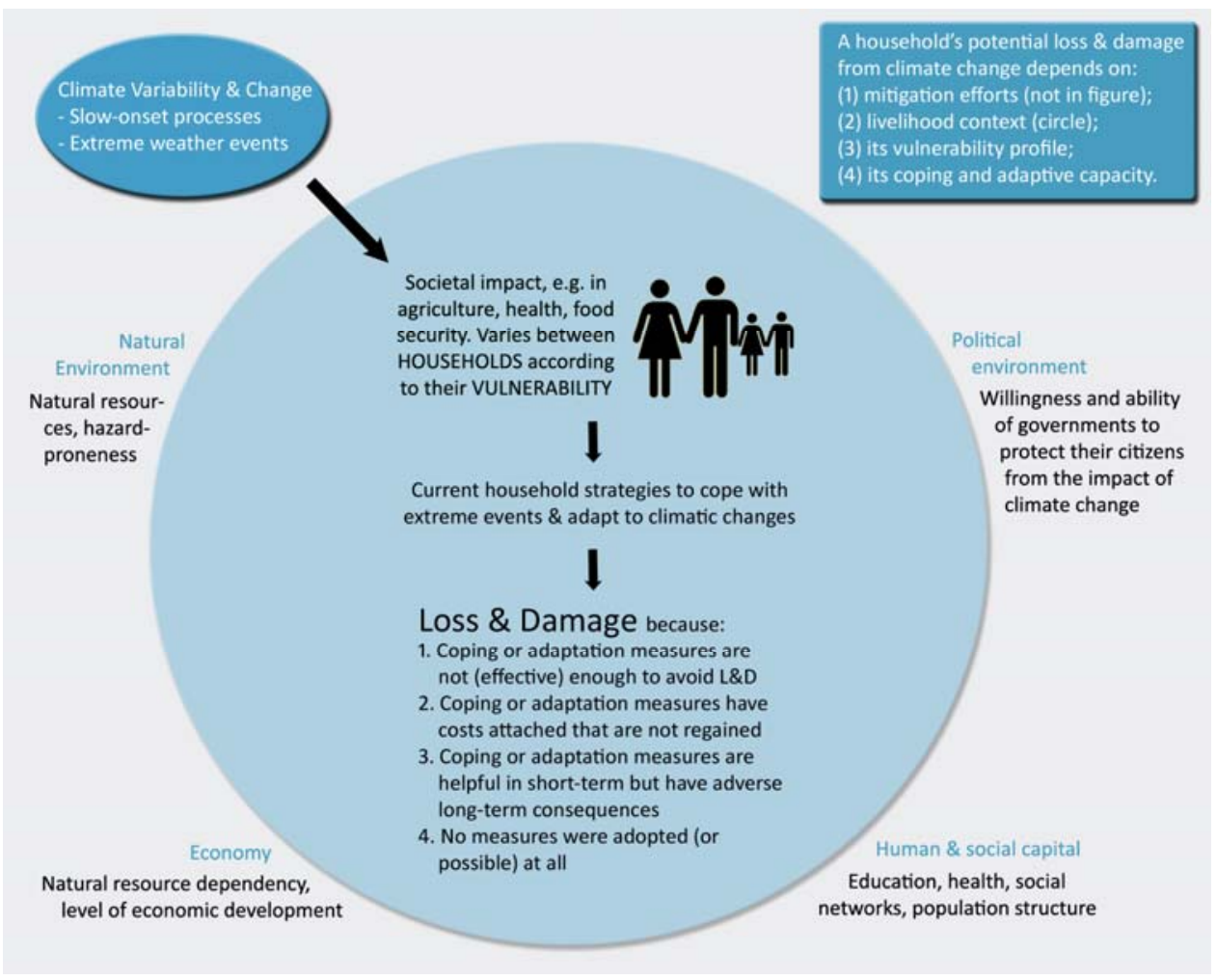

Source: Warner et al. (2012b)

\section{Four pathways to loss and damage: current evidence and patterns}

The nine community-based case studies synthesised in this paper illustrate four pathways via which vulnerable people incur loss and damage. Despite efforts to cope with impacts of extreme weather events and adapt to slow-onset climatic changes, many households across the research sites were not able to avoid adverse effects. Residual impacts of climate stressors occur when:

1 measures to cope or adapt are not enough to avoid loss and damage

2 measures have costs (economic, social, cultural, health, etc.) that are not regained 
3 measures are erosive and make people more vulnerable

4 no measures are adopted, due to:

a lack of capacity to respond to climate threat (constraints)

b coping/adaptation not possible (limits).

Figure 1 illustrates the potential of households to incur loss and damage, showing factors that affect how pathways to loss and damage can unfold. Loss and damage pathways 1 (adequacy of adaptation), 2 (costs of adaptation), and 3 (relationship of adaptation measures to sustainable development) relate particularly to opportunities and constraints to adaptation affected by economics, political decision-making, and other social choices that affect vulnerability and resilience to climate stressors. Loss and damage pathway 4 (no measures adopted) relates to constraints in capacity to adapt as well as social and physical limitations on adaptation at different scales.

In the rest of this section, we highlight key findings of the case studies, structured around the four loss and damage pathways we identified.

\subsection{Measures are not enough to avoid loss and damage}

The empirical research, conducted in nine vulnerable countries, indicated that the vast majority of households across the study sites undertake autonomous adaptation to climatic stressors. Yet efforts to cope with impacts of extreme events and to adapt to climatic changes are often not enough to avoid loss and damage to household economies, livelihoods, health, and cultural assets.

The findings from Rabbani et al. (2013) in Sathkira, Bangladesh exemplify a case where seemingly successful measures to adapt to slow-onset processes are insufficient to avoid loss and damage when the situation is aggravated by an extreme weather event. Sathkira is a coastal district facing sea-level rise and frequent cyclones. Both result in saltwater intrusion, which has a severe impact on rice cultivation, the mainstay of the local economy and the principal source of food for the majority of the population. Eightyone per cent of the survey respondents reported sharp increases in soil salinity levels, compared to just $2 \% 20$ years ago. To adapt, many farmers have planted new, saline tolerant-rice varieties. This strategy worked reasonably well until 2009, when cyclone Aila hit the area and caused a drastic increase of soil salinity. Almost all farmers in the area lost their complete harvest that year. In the two subsequent years, salinity levels remained high and rice yields were miniscule. Between 2009 and 2011, the total loss of rice harvest was US\$1.9 million for the four villages surveyed (Rabbani et al., 2013).

The Gambia case study (Yaffa, 2013) looked at the drought-prone area of the North Bank Region. Meteorological data since 1886 show a significant decrease in average annual rainfall. In 2011, the region experienced a severe drought once again, resulting in very low crop yields for some and total crop failure for others. Ninety-seven per cent of the survey respondents experienced adverse effects of the drought on their household economy. Most households tried to survive by finding alternative sources of money to buy food. Food prices rose and there was tough competition for scarce jobs. Other coping strategies, such as reliance on food relief and selling properties, were only partly 
successful or endangered future livelihood security. Despite coping measures, $64 \%$ said they had to modify their food consumption because of the drought and low harvests. Some purchased cheaper, less nutritious food, others had to reduce portion sizes or the number of meals, and the worst-off did both.

The case studies in Ethiopia (Haile et al., 2013) and Nepal (Bauer, 2013) focused on flooding. Both case studies looked more closely at preventive measures, such as digging ditches, erecting boundary walls and moving property and livestock to unaffected areas. Just as in Bangladesh, these measures were quite effective in minimising impacts from moderate floods, but fell short when the areas were hit with more severe floods.

\subsection{Measures have costs that are not regained}

The measures that households adopt to cope with impacts of extreme weather events and to adapt to slow-onset climatic changes often have costs themselves. These costs can be both monetary and non-monetary.

In Bhutan, Kusters and Wangdi (2013) looked at the impact of changing monsoon patterns on rice cultivation. The monsoon rains are starting later and the total amount of rain has reduced sharply over the past two decades. Rice farmers in the study area (Punakha District) have tried to adapt by modifying water-sharing arrangements between villages and by intensifying irrigation canal maintenance in drier years. Information from focus group discussions and expert interviews suggest that labour input for maintenance is up to ten times higher in years with poor or late rains than in years with adequate rainfall. There are significant costs attached to this, particularly because labour is scarce during the rice cultivation season. When measures to convey enough irrigation water to fields are not enough, farmers cultivate crops needing less water, such as maize, instead of rice. This has substantial costs, too. Crop yields and income from maize are 2.5 to 8 times lower than for rice. ${ }^{2}$ Eighty-seven per cent of the respondents using such measures said these involved extra monetary and non-monetary costs.

In our study areas in Mozambique, households had to deal with the double threat of droughts and floods (Brida et al., 2013). Many of the households surveyed had been resettled from lowland areas to upland areas after repeated severe flooding in 2001 and 2007. This adaptation made them less vulnerable to flooding, but it came with a very significant cost. In the upland areas, many are unable to produce enough food for their families because upland soils are less fertile and crop yields significantly lower. Some households moved their fields back to more fertile lowland areas, while living in upland areas. That gives them better yields, but valuable time and energy is wasted commuting the large distances between upland and lowland areas. Moreover, when a flood hits again, they are at risk of losing their entire harvest from lowland farms.

In our study areas in Burkina Faso and Micronesia, there were clear manifestations of cultural losses. On the island of Kosrae in the Federated States of Micronesia, there was severe damage to a cultural heritage site because the big stones of an ancient fortress had been used to erect sea walls (Monnereau and Abraham, 2013). In Northern Burkina Faso, many former pastoralists have lost their herds in recurrent droughts and have had to take up other occupations. Besides the material losses, many of these former herdsmen feel they have lost their cultural identity (Traore et al., 2013). 


\subsection{Erosive coping: short-term merits, adverse long-term effects}

People who live in risk-prone areas and who are confronted with certain climate stressors try to avoid adverse effects through preventive or proactive measures (e.g., risk spreading in agriculture and livelihood diversification). If adverse effects cannot be avoided through preventive action, but the impact is not very severe, people first employ 'non-erosive' coping measures, such as drawing on any buffers they have created. If the crisis is more severe, for example when an area is hit by drought in several consecutive years, or when several hazards strike simultaneously, the set of non-erosive coping strategies may become exhausted and people will have to take more drastic action. For instance, they may need to sell productive assets, eat into their seed stock, or take children out of school so they can seek work to support the household. These measures are 'erosive' because they can seriously jeopardise people's future livelihoods and food security (de Waal, 1989; van der Geest and Dietz, 2004). ${ }^{3}$ Across the nine case study sites, many households are forced to employ erosive coping strategies to deal with the impact of climatic stressors. These strategies allow them to survive in the short term but weaken household resilience in the longer term.

Opondo (2013) examined the coping strategies that households adopted after River Nzoia in Western Kenya broke its dykes in December 2011 and caused havoc in Budalangi Division (a low-lying area on the shores of Lake Victoria). Floods have become more frequent and intense in recent decades. The December 2011 flood drowned people and livestock, washed away crops, severely damaged houses and spawned an outbreak of water-borne diseases. Some of the coping strategies that people adopted to gain access to food or reconstruct housing have severe implications for future livelihood security. For example, some households were forced to sell their bullocks to buy food after the flood had washed away their crops. The following season, the bullocks were not available to plough the fields and the households' situation became even more precarious. Also, able-bodied household members had to invest much of their time in non-farm activities or migration to urban centres to solve their households' urgent food needs. This meant that they had much less time to spend on the household farm, which undermined food security in the next cultivation cycle. Lastly, some households withdrew their children from school so they could help generate income, mostly through non-farm activities.

The case study in the Gambia, which focused on drought impacts, yielded similar findings (Yaffa, 2013), and on the Micronesian island of Kosrae examples were found of maladaptive measures. Sea walls that were built - both by individuals and government agencies - to protect people and their properties, actually exacerbated coastal erosion, especially on the edges (Monnereau and Abraham, 2013). Lastly, the case study in Ethiopia found that when preventive measures are not enough to avoid severe flood impacts, households often rely on their social networks for survival. However, repeated floods erode this social capital, overburden social networks, and leave affected households in a more vulnerable position with each subsequent flood (Haile et al., 2013).

\subsection{No measures are adopted-or possible-at all}

Although the vast majority of respondents in the case study areas indicated that their households adopted measures to prevent or cope with impacts of climatic stressors (median: 88\%, see Table 2), there were always some households that did not adopt such 
measures. Most of these households faced constraints or limits that made it impossible for them to adjust at all. Table 6 shows reasons for not adopting coping or adaptation measures. Lack of knowledge or skills was the most common reason, followed by lack of financial means or other resources. These households did not know what do or were not able to do anything. Very few households indicated that it was not their task to do anything or that it was not a priority.

Table 6 Reasons for not undertaking coping or adaptation measures ( $\%$ of households)

\begin{tabular}{lcccc}
\hline Country & $\begin{array}{c}\text { Lack knowledge } \\
\text { or skills }\end{array}$ & $\begin{array}{c}\text { Lack means or } \\
\text { resources }\end{array}$ & 'Not my task' & No priority \\
\hline Bangladesh & 68 & 30 & 0 & 2 \\
Bhutan & 68 & 16 & 4 & 12 \\
Burkina Faso & 79 & 22 & n/a & n/a \\
Ethiopia & n/a & n/a & 3 & 2 \\
Gambia & 58 & 28 & 10 & 4 \\
Kenya & 40 & 31 & 3 & 0 \\
Micronesia & 47 & 74 & 0 & 0 \\
Mozambique & 64 & 40 & 9 & 5 \\
Nepal & 47 & 88 & 3 & 2 \\
Median & 61 & 31 & 3 & 2 \\
\hline
\end{tabular}

Note: Percentages calculated over households that did not adopt coping or adaptation measures (see Table 2)

Monnereau and Abraham (2013) studied loss and damage from coastal erosion and storm surges on the island of Kosrae in the Federated States of Micronesia. Kosrae has much higher levels of human and economic development than the other study sites. However, a relatively high proportion $(40 \%$, see Table 2$)$ of respondents did not adopt any adaptation measures to prevent impacts of coastal erosion and storm surges, and $74 \%$ indicated that the reason for that was lack of financial means or other resources. This is because the most common adaptation options they have are too expensive or seem inefficient. For example, people may refrain from building a sea wall to protect their house, land and other property because they lack resources and because they have seen from neighbours that building a sea wall is no guarantee that impacts are avoided.

When faced with such adaptations limits or constraints, households and communities have to make difficult choices: changing their objectives, accepting loss and damage, or undertaking more significant transformation (see Preston et al., 2013; Kates et al., 2012). Changing objectives often involves a deteriorating standard of living, the loss of cultural values, and the disintegration of commonly held values and practices in the community. Accepting loss and damage often means falling incomes, assets, education levels and social status, along with greater poverty, lower food consumption, and diminished future prospects. Undertaking more significant transformation can involve more permanent migration out of one's home area, leading to other significant changes in livelihood and social systems. 


\section{Conclusions and policy implications}

This concluding section points to implications for policy and research. As the evidence presented in this special issue shows, loss and damage is already a significant consequence of inadequate mitigation of, and adaptation to, climatic changes across the world. The research presented here tells a story of community efforts to adjust to the negative impacts of climatic stressors, and the consequences when communities approach barriers or limits to successful adaptation.

The research presented here tells household stories of 'just getting by', suggesting that at some scales and in some regions human societies already exist precariously between the borders of 'safe' and 'unsafe' operating spaces at the adaptation frontier (cf. Preston et al., 2013). Such households and communities face barriers that erode livelihoods, food security and asset bases and that prevent them from accessing appropriate, sufficient adaptation options to manage climatic risks. Resulting loss and damage patterns can be seen in all the case studies.

The case findings in this special issue suggest that some of the most notable current impacts are on household food production and livelihoods. A minority of households in the study areas have a great diversity of assets and access to a variety of adaptation and risk management options. Such households have diverse livelihoods, strong social networks, access to community or government support programmes and often a high level of education. This enables them to cope with adverse weather events without becoming more vulnerable, and to adapt to climatic changes in ways that enhance resilience. Of concern, however, are the more numerous vulnerable households that have the least access to such options. They have few or no viable livelihood diversification opportunities, not enough land, limited access to support programmes and little education. To survive when a climatic stressor strikes, they are often forced to use erosive coping measures, which can trap them in a downward slope of declining well-being and security. Such households experience diminishing coping and adaptive capacity and increasing loss and damage.

Our findings suggest that current loss and damage patterns strike at the very purpose of climate policy - and especially the purpose of the UNFCCC (Article 2): "to achieve (...) stabilization of greenhouse gas concentrations in the atmosphere at a level that would prevent dangerous anthropogenic interference with the climate system. Such a level should be achieved within a time-frame sufficient to allow ecosystems to adapt naturally to climate change, to ensure that food production is not threatened and to enable economic development to proceed in a sustainable manner" [UNFCCC, (1992), p.14]. Loss and damage patterns revealed in the case studies illustrate that people in vulnerable countries already appear to be approaching the biophysical and social boundaries of adaptation, beyond which climate change compromises sustainable development. The case studies show how climate-related losses relate to the central policy objectives of many countries: economic development, poverty reduction, livelihood and food security, health, education, access to usable water, and overall human welfare.

Questions arise about how to deal with those negative biophysical impacts of climate change for which no clear, practicable alternatives exist within the boundaries of our current values, culture and economic systems. Such impacts might be seen as climate change begins to affect the functionality of some low-lying island countries. Further questions arise about how to deal with potentially reduced habitability of coastal zones 
and dryland areas - many of which host dense human population concentrations, including mega-cities. The potential changes that science suggests may be felt as early as this century raise questions about the ability of environmental systems to adjust naturally. Further questions arise about whether food production, and the associated livelihoods of an estimated 2.6 billion people, ${ }^{4}$ will be able to continue in a sustainable manner.

One striking aspect of this analysis is that only the fourth loss and damage pathway that we identified (no measures are adopted - or possible - at all) is related to "hard limits' where no measures are possible. For the other loss and damage pathways, a more nuanced interplay between climatic stressors and their impacts on societal values can and needs to be addressed by increasing adaptive capacity, reducing exposure and vulnerability, and undertaking measures that increase the ability of affected people to adjust to the stressors they face within their social-ecological systems.

\subsection{Policy implications}

At the climate negotiations in Warsaw, Poland (COP19) in December 2013, there is a mandate to establish institutional arrangements to address loss and damage associated with the impacts of climate change ${ }^{5}$ (UNFCCC, 2012), including functions and modalities. ${ }^{6}$ The work on loss and damage under the UNFCCC is envisioned to contribute to the formulation of the anticipated international climate agreement at COP21 (Paris, December 2015).

The four pathways to loss and damage suggest that policies to address loss and damage must consider:

- Mitigation of greenhouse gas emissions (strong influence on all pathways to loss and damage). Success in avoiding situations in which society faces loss and damage particularly under pathway $4 \mathrm{~b}$ - depends on appropriately ambitious mitigation decisions today.

- Policies geared towards addressing, restoring or otherwise making up for adaptation costs that are not regained are especially relevant for pathway 2 .

- Policies geared toward increasing resilience (such as reducing exposure, addressing underlying vulnerabilities that affect the coping and adaptive capacity of affected people) are relevant for pathways 1,3 , and $4 \mathrm{a}$. The research showed that many households surveyed employ a variety of approaches to get by, although many of these have longer-term erosive implications for livelihoods and well-being. If social vulnerabilities to climatic and other stressors are root causes of loss and damage, then improving social resilience provides some of the solutions.

- Finally, questions arise about what policies may be appropriate and needed to address situations where adaptation measures to particular kinds of climatic stressors are no longer possible (pathway $4 \mathrm{~b}$ ). In such areas, there are already limits to adaptation due to issues such as the scope of the biophysical impact or the degree to which a society can deal with the impact. Policy approaches are needed that clearly set out the consequences of approaching and surpassing hard limits (at all levels). Tools are needed to identify decision points and define options for decision pathways. 
Vulnerable countries like those studied in this research are at the frontline of loss and damage realities and policy solutions. The case studies conducted for the Loss and Damage in Vulnerable Countries Initiative represent a first generation of research systematically assessing residual impacts of changes in weather variability and climate patterns at household level. The loss and damage pathways, identified in this article, serve as a point of departure for further research to understand how climate change affects society today, and the possible consequences of adaptation shortfalls in the future.

\section{References}

Adger, W.N., Dessai, S., Goulden, M., Hulme, M., Lorenzoni, I., Nelson, D.R., Naess, L.O., Wolf, J. and Wreford, A. (2009a) 'Are there social limits to adaptation to climate change?', Climatic Change, Vol. 93, Nos. 3-4, pp.335-354.

Adger, W.N., Huq, S., Brown, K., Conway, D. and Hulme, M. (2003) 'Adaptation to climate change in the developing world', Progress in Development Studies, Vol. 3, No. 3, pp.179-195.

Adger, W.N., Lorenzoni, I. and O’Brien, K. (Eds.) (2009b) Adapting to Climate Change: Thresholds, Values, Governance, Cambridge University Press, Cambridge.

Barnett, J. and O'Neill, S. (2010) 'Maladaptation', Global Environmental Change, Vol. 20, No. 2, pp.211-213.

Bauer, K. (2013) 'Are preventive and coping measures enough to avoid loss and damage from flooding in Udayapur District, Nepal?', International Journal of Global Warming.

Bebbington, A. (1999) 'Capitals and capabilities: a framework for analysing peasant viability, rural livelihoods and poverty', World Development, Vol. 27, No. 12, pp.2021-2044.

Berrang-Ford, L., Ford, J.D. and Paterson, J. (2011) 'Are we adapting to climate change?', Global Environmental Change, Vol. 21, No. 1, pp.25-33.

Birkmann, J. (2011) 'First- and second-order adaptation to natural hazards and extreme events in the context of climate change', Natural Hazards, Vol. 58, No. 2, pp.811-840.

Brida, A.B., Owiyo, T. and Sokona, Y. (2013) 'Loss and damage from the double blow of flood and drought in Mozambique', International Journal of Global Warming.

Burton, I. (2009) 'Climate change and the adaptation deficit', in Schipper, E.L.F. and Burton, I. (Eds.): Earthscan Reader on Adaptation to Climate Change, Earthscan, London, pp.89-95.

Davies, S. (1996) Adaptable Livelihoods: Coping with Food Insecurity in the Malian Sahel, MacMillan Press, London.

De Waal, A. (1989) 'Is famine relief irrelevant to rural people?', IDS Bulletin, Vol. 20, No. 2, pp.63-67.

Di Falco, S. and Bulte, E. (2009) Social Capital and Weather Shocks in Ethiopia: Climate Change and Culturally-induced Poverty Traps, London School of Economics, Working Paper.

Ellis, F. (1998) 'Household strategies and rural livelihood diversification', The Journal of Development Studies, Vol. 35, No. 1, pp.1-38.

Fung, R., Lopez, A. and New, M. (2011) 'Water availability in $+2^{\circ} \mathrm{C}$ and $+4{ }^{\circ} \mathrm{C}$ worlds', Philosophical Transactions of the Royal Society A, Vol. 369, No. 1934, pp.99-116.

Haile, A.T., Wagesho, N. and Kusters, K. (2013) 'Loss and damage from flooding in the Gambela Region, Ethiopia', International Journal of Global Warming.

Hertel, T.W., Burke, M.B. and Lobell, D.B. (2010) 'The poverty implications of climate-induced crop yield changes by 2030', Global Environmental Change, Vol. 20, No. 4, pp.577-585.

Hickey, S. and Bracking, S. (2005) 'Exploring the politics of chronic poverty: from representation to a politics of justice?', World Development, Vol. 33, No. 6, pp.851-865. 
Intergovernmental Panel on Climate Change (IPCC) (2007a) Climate Change 2007: The Physical Science Basis, Summary for Policy Makers, Contribution of Working Group I to the Fourth Assessment Report of the Intergovernmental Panel on Climate Change, Cambridge University Press, Cambridge and New York.

Intergovernmental Panel on Climate Change (IPCC) (2007b) Climate Change 2007: Climate Change Impacts, Adaptation and Vulnerability, Summary for Policy Makers, Contribution of Working Group II to the Fourth Assessment Report of the Intergovernmental Panel on Climate Change, Cambridge University Press, Cambridge and New York.

Intergovernmental Panel on Climate Change (IPCC) (2012) Managing the Risks of Extreme Events and Disasters to Advance Climate Change Adaptation, a Special Report of Working Groups I and II of the Intergovernmental Panel on Climate Change, Cambridge University Press, Cambridge and New York.

Kates, R.W., Travis, W.R. and Wilbanks, T.J. (2012) 'Transformational adaptation when incremental adaptations to climate change are insufficient', $P N A S$, Vol. 109, No. 19, pp.7156-7161.

Kusters, K. and Wangdi, N. (2013) 'The costs of adaptation: Changes in water availability and farmers' responses in Punakha district, Bhutan', International Journal of Global Warming.

McGray, H., Hammill, H., Bradley, R., Schipper, E.L.F. and Parry, J.E. (2007) Weathering the Storm: Options for Framing Adaptation and Development, World Resources Institute, Washington, DC.

Meinshausen, M., Meinshausen, N., Hare, W., Raper, S.C.B., Frieler, K., Knutti, R., Frame, D.J. and Allen, M.R. (2009) 'Greenhouse-gas emission targets for limiting global warming to $2{ }^{\circ} \mathrm{C}$ ', Nature, Vol. 458, No. 7242, pp.1158-1163.

Monnereau, I. and Abraham, S. (2013) 'Limits to autonomous adaptation in response to coastal erosion in Kosrae, Micronesia', International Journal of Global Warming.

Moser, S.C. (2009) 'Adapting to climate change: thresholds, values and governance', in Adger, W.N., Lorenzoni, I. and O'Brien K. (Eds.): Adapting to Climate Change: Thresholds, Values, Governance, pp.313-334, Cambridge University Press, Cambridge.

Moser, S.C. and Ekstrom, J.A. (2010) 'A framework to diagnose barriers to climate change adaptation', PNAS, Vol. 107, No. 51, pp.22026-22031.

O'Brien, K. (2010) 'Do values subjectively define the limits to climate change adaptation?', in O'Brien, K., Adger, W.N. and Lorenzoni, I. (Eds.): Adapting to Climate Change: Thresholds, Values, Governance, pp.164-180, Cambridge University Press, Cambridge.

O'Brien, K. and Wolf, J.A. (2010) 'A values-based approach to vulnerability and adaptation to climate change', WIREs Climate Change, Vol. 1, No. 2, pp.232-242.

Opondo, D. (2013) 'Erosive coping after the 2011 floods in Kenya', International Journal of Global Warming.

Patt, A.G. and Schröter, D. (2008) 'Perceptions of climate risk in Mozambique: implications for the success of adaptation strategies', Global Environmental Change, Vol. 18, No. 3, pp.458-467.

Preston, B.L., Dow, K. and Berkhout, F. (2013) 'The climate adaptation frontier', Sustainability, Vol. 5, No. 3, pp.1011-1035.

Rabbani, G., Rahman, A. and Mainuddin, K. (2013) 'Salinity induced loss and damage to farming households in coastal Bangladesh', International Journal of Global Warming.

Rademacher-Schulz, C., Afifi, T., Warner, K., Rosenfeld, T., Milan, A., Etzold, B. and Sakdapolrak, P. (2012) 'Rainfall variability, food security and human mobility: an approach for generating empirical evidence', InterSecTions, No. 10, United Nations University Institute for Environment and Human Security (UNU-EHS), Bonn.

Röckstrom, J. et al. (2009) 'A safe operating space for humanity’, Nature, Vol. 461, pp.472-475.

Schipper, E.L.F. (2007) Climate Change Adaptation and Development: Exploring the Linkages, Working Paper 107, Tyndall Centre for Climate Change Research, Norwich.

Scoones, I. (1998) Sustainable Rural Livelihoods: A Framework for Analysis, IDS Working Paper 72, Institute of Development Studies, Brighton. 
Thornton, P.K., Jones, P.G., Ericksen, P.J. and Challinor, A.J. (2011) 'Agriculture and food systems in Sub-Saharan Africa in a $4^{\circ} \mathrm{C}$ world', Philosophical Transactions of the Royal Society A, Vol. 369, No. 1934, pp.117-136.

Traore, S., Owiyo, T. and Sokona, Y. (2013) 'Dirty drought causing loss and damage in Northern Burkina Faso', International Journal of Global Warming.

UNFCCC (1992) United Nations Framework Convention on Climate Change [online] http://unfccc.int/resource/docs/convkp/conveng.pdf (accessed 18 August 2013).

UNFCCC (2012) 1/CP18. Doha Gateway Decision, United Nations Framework Convention on Climate Change Meetings [online] http://unfccc.int/2860.php\#decisions (accessed 30 January 2013).

van der Geest, K. (2004) 'We're Managing!' Climate Change and Livelihood Vulnerability in Northwest Ghana, African Studies Centre, Leiden.

van der Geest, K. and Dietz, T. (2004) 'A literature survey about risk and vulnerability in drylands, with a focus on the Sahel', in Dietz, T., Rueben, R. and Verhagen, J. (Eds.): The Impact of Climate Change on Drylands, Kluwer, Dordrecht, pp.117-146.

van Vliet, J., van der Berg, M., Schaeffer, M., van Vuuren, D.P., den Elzen, M., Hof, A.F., Beltran, A.M. and Meinshausen, M. (2012) 'Copenhagen accord pledges imply higher costs for staying below $2^{\circ} \mathrm{C}$ warming', Climatic Change, Vol. 113, No. 2, pp.551-561.

Warner, K., Afifi, T., Henry, K., Rawe, T., Smith, C. and de Sherbinin, A. (2012a) Where the Rain Falls: Climate Change, Food and Livelihood Security, and Migration, Global Policy Report of the Where the Rain Falls Project, Bonn, UNU and CARE.

Warner, K., van der Geest, K., Kreft, S., Huq, S., Kusters K. and de Sherbinin A. (2012b) Evidence from the Frontlines of Climate Change: Loss and Damage to Communities Despite Coping and Adaptation, Loss and Damage in Vulnerable Countries Initiative, Policy Report, Report No. 9, United Nations University Institute for Environment and Human Security (UNU-EHS), Bonn.

Yaffa, S. (2013) 'Coping measures not enough to avoid loss and damage from drought in the North Bank Region of The Gambia', International Journal of Global Warming.

\section{Notes}

1 The data presented in this paper was gathered in the context of the Loss and Damage in Vulnerable Countries Initiative. As part of this project, the United Nations University, together with national researchers conducted nine case studies about impacts of climate variability and climate change on local communities, their strategies to deal with these stressors, and residual loss and damage. Fieldwork took place in Bangladesh, Bhutan, Burkina Faso, Ethiopia, the Gambia, Kenya, Micronesia, Mozambique and Nepal. Funding for the Loss and Damage in Vulnerable Countries Initiative came from the Climate Development Knowledge Network (CDKN). The Africa Climate Policy Center (ACPC) funded three case studies (Ethiopia, Burkina Faso and Mozambique). For more information about the project, go to http://www.lossanddamage.net.

2 The estimation of 2.5 times is based on FAO data for rice and maize yields and prices in Punakha District, Bhutan (2000-2010). Data from the Bhutanese Ministry of Agriculture and Forestry suggest an even larger difference (eight times). See Kusters and Wangdi (2013) for more details.

3 Other studies have also found that measures undertaken to cope with and adapt to climate stressors can actually make households more vulnerable to these and other stressors, and exacerbate poverty traps (e.g., Di Falco and Bulte, 2009; Barnett and O'Neill, 2010; Hertel et al., 2010; Hickey and Bracking, 2005) 
4 According to the statistics division of the Food and Agriculture Organization of the United Nations (http://faostat.fao.org), the world's 'agricultural population' amounted to $2,621,037,000$ people in 2012. FAO defines agricultural population as all persons depending for their livelihood on agriculture, hunting, fishing and forestry. It comprises all persons economically active in agriculture as well as their non-working dependants (http://faostat3.fao.org/home/index.html\#METADATA_GLOSSARY).

5 Paragraph 9 of the Doha Climate Gateway decision reads: "Decides to establish, at its nineteenth session, institutional arrangements, such as an international mechanism, including functions and modalities, elaborated in accordance with the role of the Convention as defined in paragraph 5 above, to address loss and damage associated with the impacts of climate change in developing countries that are particularly vulnerable to the adverse effects of climate change."

6 See UNFCC (2012) paras 7 and 10. 